\title{
AEROTHERMAL ANALYSIS OF INSULATION TO PROTECT EXHUAST DUCTS OF A PUSHER TURBO PROP ENGINE AIRCRAFT
}

\author{
Vinay C A1 ${ }^{1}$, Bhaskar Chakravarthy ${ }^{1}$ \\ ${ }^{1}$ National Aerospace Laboratories, Bangalore Karnataka, India
}

\begin{abstract}
Engine exhaust stubs should be insulated to minimize heating of the nacelle. Nacelle material being aluminium the temperature rise due to hot exhaust gases should not deteriorate the characteristics of the aluminium material. To meet this requirement a heat shield should be installed on the portion of the engine exhaust duct internal to the nacelle. This paper describes aero-thermal relations used in selecting the insulation to protect exhaust ducts, assuming only the air flow due to natural convection and the emissivity of the duct material and the constraint is that the target cold surface temperature should be less than $200^{\circ} \mathrm{C}$. Having chosen the insulation, tests were conducted on the aircraft and the results show that the objective is met with the calculated target cold surface temperature limit.
\end{abstract}

Keywords: Engine, exhaust duct, cold surface, nacelle

\section{Introduction}

To reduce the temperature of the structure in the vicinity of the exhaust duct and to eliminate the possibility of fuel or oil coming in contact with the hot parts of the engine, it is sometimes necessary to provide insulation on the exhaust duct of gas turbine engines. The exhaust duct surface temperature is usually quite high. A typical insulation blanket and the temperatures obtained at various locations are shown in Figure 1. This blanket contains fiberglass as the low conductance material and aluminum foil as the radiation shield. The blanket is suitably covered so that it does not become oil soaked. Insulation blankets have been used rather extensively on many installations in which long exhaust is needed. (1). This paper describes aero-thermal relations used in selecting the insulation to protect exhaust ducts, assuming only the air flow due to natural convection and the emissivity of the duct material with a target cold surface temperature of less than $200^{\circ} \mathrm{C}$. Having chosen the insulation, the tests were conducted on the aircraft to demonstrate the objective and the results from the ground tests carried out on the aircraft during engine ground runs showed that the objective is met within the calculated target cold surface temperature limit.

adfa, p. 1, 2011.

(C) Springer-Verlag Berlin Heidelberg 2011 


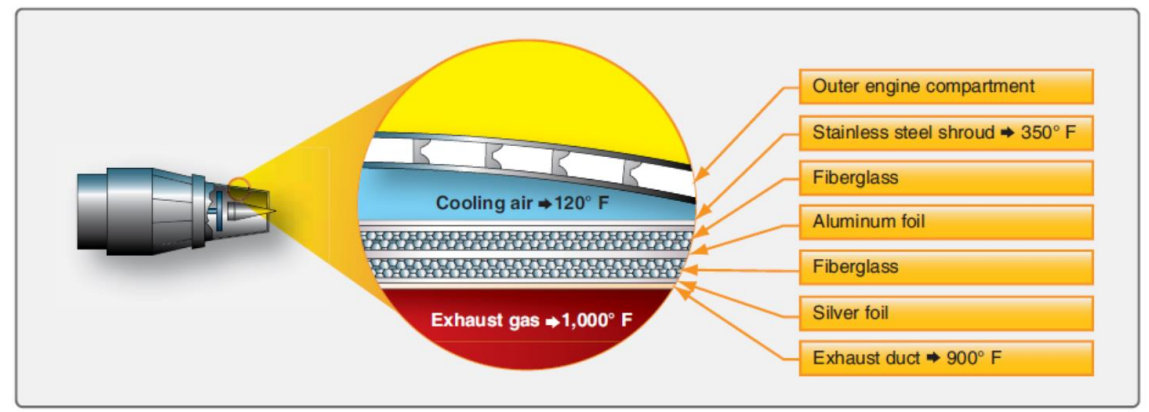

Fig.1. Typical Engine Insulation blanket

\section{Thermal Analysis}

For the purpose of analysis engine exhaust duct flow is assumed as hot fluid flowing through the pipe and the surface temperature is calculated for an insulated pipe with convective fluid flow across the surface. Figure 2 shows the scenario. A thermal analysis is carried out with the data and assumptions as below.

\subsection{Data and Assumptions}

Table 1.

\begin{tabular}{|l|l|}
\hline Duct Material & Nimonic Alloy \\
\hline Hot face Temperature & $600{ }^{\circ} \mathrm{C}$ \\
\hline Exhaust temperature, $\mathrm{T}_{\text {limit }}$ & $648.8^{\circ} \mathrm{C}$ \\
\hline Ambient temperature & $45^{\circ} \mathrm{C}$ \\
\hline Target cold face temperature & $<200^{\circ} \mathrm{C}$ \\
\hline Air speed & $0.1 \mathrm{~m} / \mathrm{s}$ \\
\hline Max. Thickness available & $25 \mathrm{~mm}$ \\
\hline Emissivity of cladding, $\varepsilon$ & 0.4 \\
\hline Pipe outside diameter, Pipe & $300 \mathrm{~mm}$ \\
\hline Insulation thickness $\mathrm{I}_{\text {thickness }}$ & $12.7 \mathrm{~mm}$ \\
\hline Insulation density, $\mathrm{I}_{\text {density }}$ & $256 \mathrm{~kg} / \mathrm{m}^{3}$ \\
\hline $\begin{array}{l}\text { Stefanï Boltzmann constant, } \\
\sigma\end{array}$ & $5.67 \times 10^{-8} \mathrm{Wm}^{-2} \mathrm{k}^{4}$ \\
\hline
\end{tabular}




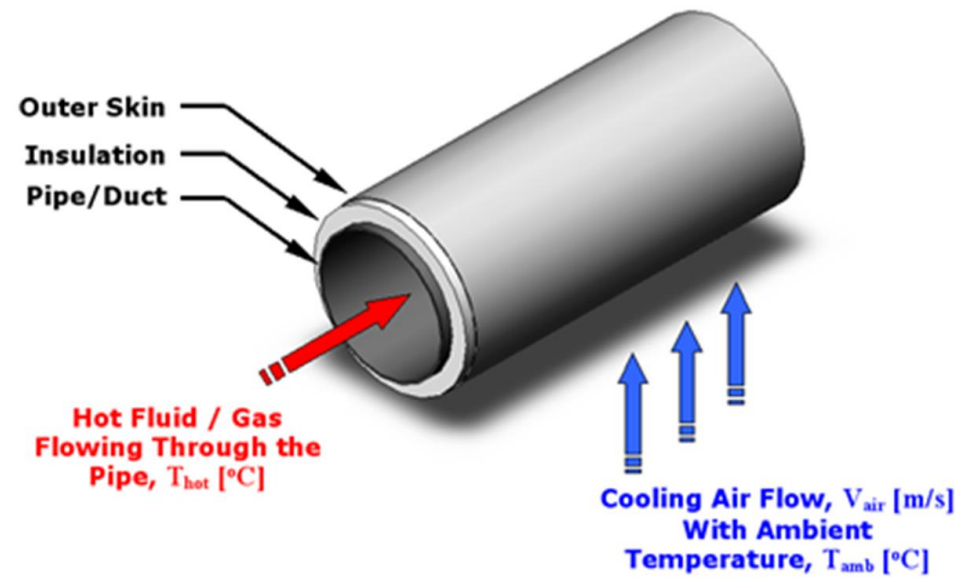

Fig.2. Hot Fluid/Gas Flow through the Pipe

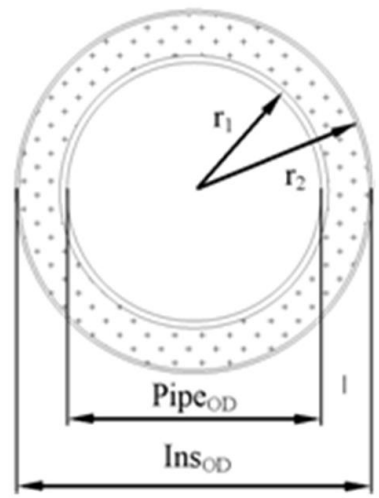

Fig.3. Nomenclature

\subsection{Geometry data}

Pipe outside diameter,

Outside diameter with insulation

(Neglecting skin thickness):

$$
\text { Pipe }_{\mathrm{OD}}=300 \mathrm{~mm}
$$

Ins $_{\mathrm{OD}}=$ Pipe $_{\mathrm{OD}}+2 \mathrm{I}_{\text {thickness }}$

Thus giving

$$
r 1=\frac{\text { Pipe }_{O D}}{2}=150 \mathrm{~mm}
$$




$$
r 2=\frac{I n s_{O D}}{2}=162.7 \mathrm{~mm}
$$

\subsection{Insulation Thermal Data}

The plotted data shown in the Fig.4 below with points shown as + shows the manufacturers given data for thermal conductivity as a factor of temperature and this has been detailed as second order polynomial equation.

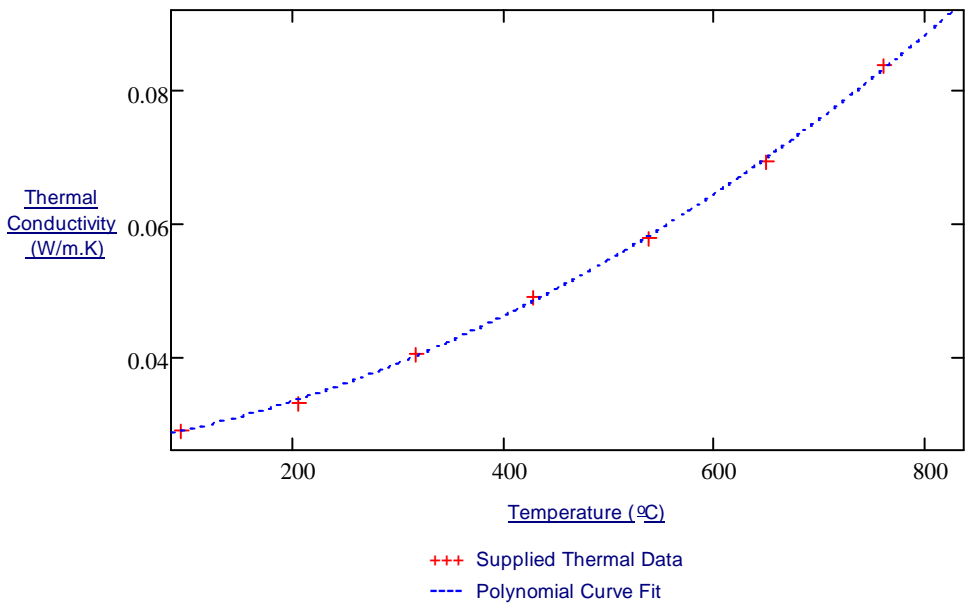

Fig.4. Thermal Conductivity Values

\subsection{Calculations}

Cooling air flow:

$0.1 \mathrm{~m} / \mathrm{s}$

Cooling air surface co-efficient:

$$
\begin{aligned}
& m=\sqrt{2.857 V_{\text {air }}+1} \\
& m=1.1
\end{aligned}
$$

From the equations of thermal equilibrium ( Ref 2$)$

Mean temperature across the insulation:

$T_{\text {mean }}=\frac{T_{\text {hot }}+T_{\text {surf }}}{2}$ 
Thermal conductivity as a factor of temperature:

$$
k=A \operatorname{val}\left(T_{\text {mean }}-273\right)^{2}+B \operatorname{val}\left(T_{\text {mean }}-273\right)+C \operatorname{val}
$$

Heat transfer Co-efficient:

$$
h=1.97 m\left(T_{\text {surf }}-T a m b\right)^{0.25}+\sigma \frac{\varepsilon}{2-\varepsilon} x \frac{T_{\text {surf }}{ }^{4}-T_{\text {amb }}{ }^{4}}{T_{\text {surf }}-T_{\text {amb }}}
$$

$$
\text { (Convection) }
$$

(Radiation)

Insulation surface temperature:

$$
T_{\text {surf }}=T_{a m b}+\frac{q}{h}
$$

Where Heat flux ..,

$$
q=k \frac{T_{h o t}-T_{\text {surf }}}{r_{2} \ln \left(\frac{r_{2}}{r_{1}}\right)}
$$

Using simultaneous equation solver:

$$
\left(\begin{array}{l}
T_{\text {mval }} \\
k_{\text {val }} \\
h_{\text {val }} \\
T_{\text {sval }} \\
q_{\text {val }}
\end{array}\right)=\operatorname{Find}\left(T_{\text {mean }}, k, h, T_{\text {surf }}, q\right)
$$

Thus from the above we find:

$$
\begin{aligned}
& T_{\text {sval }}-273=177.7^{\circ} \mathrm{C} \\
& T_{\text {mavl }}-273=388.9^{\circ} \mathrm{C} \\
& h_{\text {val }}=10.898 \\
& k_{\text {val }}=0.045 \\
& q_{\text {val }}=1.447 \times 10^{3}
\end{aligned}
$$




\section{Experimental Results}

Engine ground runs were conducted to evaluate the effectiveness of the thermal insulation blanket wrapped around the engine exhaust ducts as shown in Fig 4. To evaluate the effectiveness the test condition considered was ground static runs operating the engines up to full power which is the critical case in which hot exhaust gas temperature will be maximum i.e. $\sim 600^{\circ} \mathrm{C}$. Engine compartment is divided into three zones separated by firewalls. Zone temperatures are measured at 11 places ( 6 casing and 5 free air-zones) to establish that temperatures are maintained within stipulated limits by circulating ventilation air. Fig. 4 gives the location of the zone and casing temperatures measurement and zone 3 is the location of the engine exhaust ducts. The nacelle outer skins are of composite and aluminum alloy. Temperatures on skin are measured during ground run after shut down to establish that temperatures are within allowable limits. A typical engine ground run data is shown in Table 3. A typical engine ground run telemetry data plot is shown at Fig 5. Temperature measured are shown in Table 4 , from the results it could be seen that the temperatures are well within the permissible limits and hence the thermal insulation of engine exhaust duct is effective and not contributing for local temperature rise either on the nacelle skin or in the engine compartments.

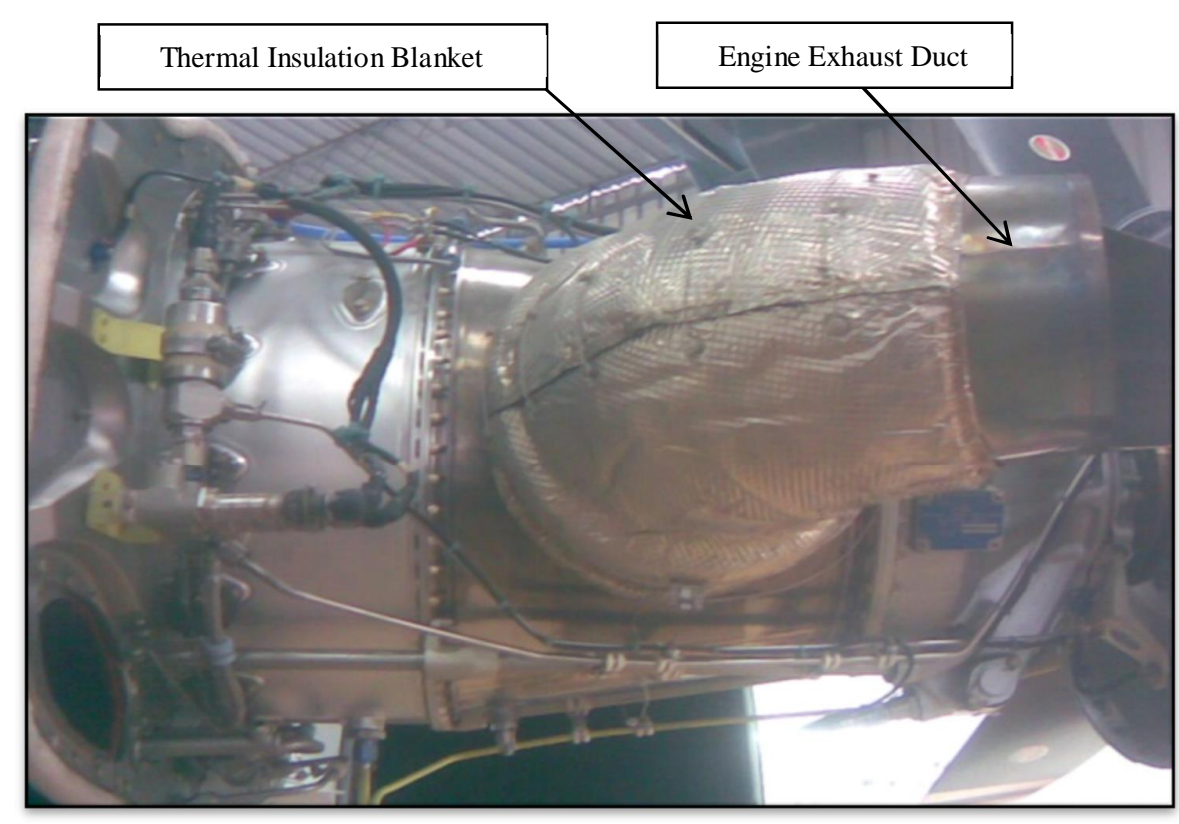

Fig.5.Thermal Insulation Blanket Installed on Exhaust Ducts 


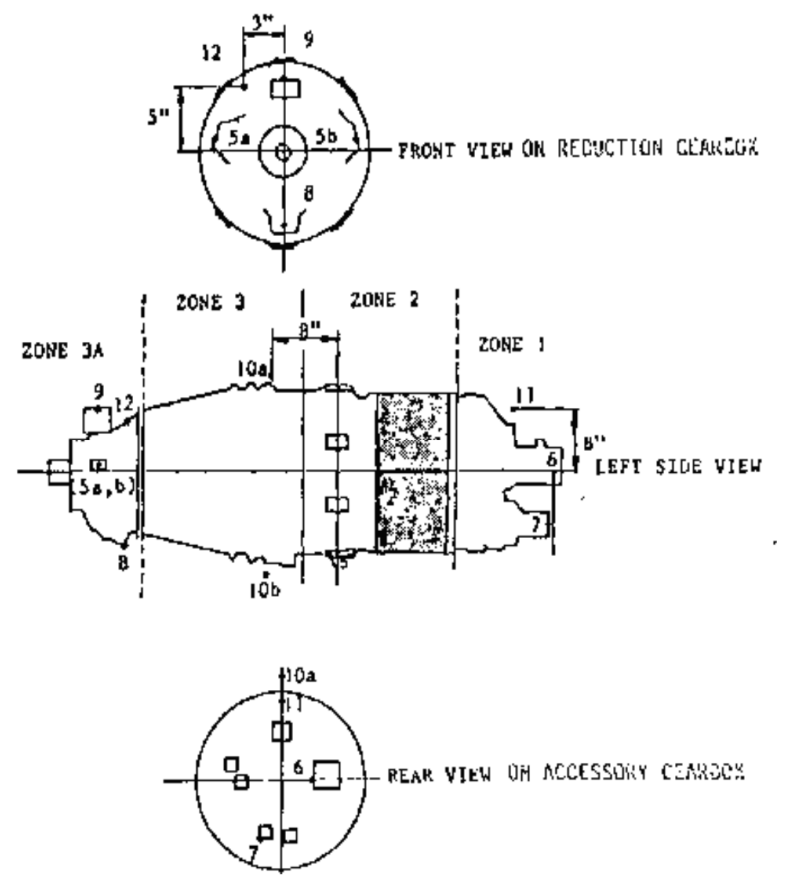

Fig.6. Zone and Component Temperature Measurement Locations on the Engine

Table 2. LH \&RH Engine Nacelle Skin Temperatures

\begin{tabular}{|c|c|c|c|}
\hline $\mathrm{S} / \mathrm{N}$ & \multicolumn{2}{|c|}{$\begin{array}{c}\text { Temperature Measurement } \\
\text { Location }\end{array}$} & $\begin{array}{c}\text { Measured } \\
\text { Temperature, }{ }^{\circ} \mathrm{C}\end{array}$ \\
\hline 1 & \multirow{4}{*}{$\begin{array}{l}\text { Rear } \\
\text { Nacelle } \\
\text { (Engine } \\
\text { Exhaust } \\
\text { Stubs) }\end{array}$} & In Board Top & 102 \\
\hline 2 & & In Board Bottom & 91 \\
\hline 3 & & Out Board Top & 106 \\
\hline 4 & & Out Board Bottom & 95 \\
\hline
\end{tabular}

*Temperature Sticker Range Selected is $88^{\circ} \mathrm{C}$ to $140^{\circ} \mathrm{C}$. 
Table 3.Measured Zone and Component Temperature

\begin{tabular}{|c|c|c|c|c|}
\hline \multicolumn{2}{|c|}{$\begin{array}{c}\text { Component Location (Fig 4) } \\
\text { Manner of Measurement }\end{array}$} & \multicolumn{2}{|c|}{ Permissible Temperature } & \multirow{2}{*}{$\begin{array}{l}\text { Engine } \\
\text { Ground Test } \\
\text { Results, }{ }^{\circ} \mathrm{C}\end{array}$} \\
\hline & & $\begin{array}{l}\text { Max. } \\
\text { Temp }{ }^{\circ} \mathrm{C}\end{array}$ & $\begin{array}{l}\text { Max. } \\
\text { Transient } \\
\text { Temp }{ }^{\circ} \mathrm{C} \\
(15 \text { secs })\end{array}$ & \\
\hline $5-9$ & $\begin{array}{l}\text { Washer type } \\
\text { Thermocouple. }\end{array}$ & 121 & 150 & 84 \\
\hline $\begin{array}{c}\text { Zone } 1 \\
\text { Location } 11\end{array}$ & $\begin{array}{l}\text { Free air - open } \\
\text { bead type ther- } \\
\text { mocouple. }\end{array}$ & 121 & 150 & 67 \\
\hline $\begin{array}{c}\text { zone } 3 \mathrm{~A} \\
\text { Location } 12\end{array}$ & $\begin{array}{l}\text { Free air - open } \\
\text { bead type ther- } \\
\text { mocouple. }\end{array}$ & 150 & 177 & 98 \\
\hline $\begin{array}{c}\text { Zone } 3 \\
\text { Location } 10\end{array}$ & $\begin{array}{l}\text { Free air - open } \\
\text { bead type ther- } \\
\text { mocouple. }\end{array}$ & 204 & 204 & 132 \\
\hline zone 2 & $\begin{array}{l}\text { Free air - open } \\
\text { bead type ther- } \\
\text { mocouple. }\end{array}$ & 93.3 & 93.3 & 63 \\
\hline
\end{tabular}

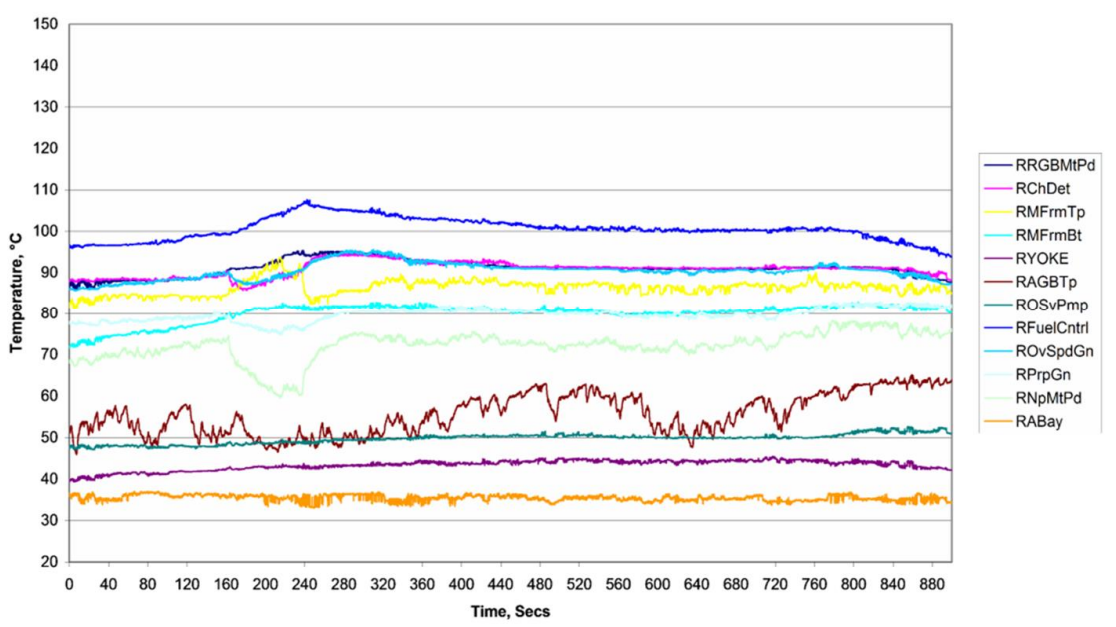

Fig.7.Engine Zone and Bay Temperature RH Engine 


\section{Conclusion}

From the experimental test results discussed in section 3 , it can be seen that the purpose of introducing the thermal insulation blanket is met. Thus, the temperature of the structure i.e. nacelle skin made from aluminium material, which is in the vicinity of the exhaust duct is in the safe temperature exposure limits. It can be seen that the measured zone $\left(132^{\circ} \mathrm{C}\right)$ and nacelle skin $\left(\max 106^{\circ} \mathrm{C}\right)$ temperatures are well below the estimated/calculated cold surface temperature of $\left(\mathrm{T}_{\text {sur }}\right) 177^{\circ} \mathrm{C}$ as discussed in section 2 .

\section{$5 \quad$ Acknowledgements}

The authors wish to thank all partners and associated partners for their contribution to the program and for their permission to publish this paper.

\section{References}

1. Aviation Maintenance Technician Handbook-Powerplant Volume-2, FAA-H-8083-32, US department of Transportation, 2012.

2. A Heat Transfer Textbook, John H Lienhard, Phlogiston Press, USA, 2008. 